\section{Alberto Lázaro}

University of Alcalá, Spain
2017, Vol. 14 (2), 69-81(122)

revije.ff.uni-lj.si/elope

doi: 10.4312/elope.14.2.69-81

UDC: $821.111 .09-344 \ll 17 / 19 \lll$

\title{
The Dark Side of British Horror Fiction: Politics, Taboos and Censorship
}

\begin{abstract}
Nearly two and a half centuries have passed since the first British Gothic novels began to attract attention with their pages full of monstrous characters, excessive violence, explicit sexual content and all kinds of horrific scenes. For the most part, the reception of this type of literature has been very positive, though not exempt from controversies. This paper seeks to show how, beyond the alluring mystery, inventive plots and attraction of the dark side, British horror fiction appeals to the reader's inner desires and imagination by means of transgressive political, religious or sexual contents that often defy taboos and social decorum. To illustrate this argument, three well-known authors and texts from three different periods will be discussed: Matthew Gregory Lewis's The Monk (1796), Joseph Sheridan Le Fanu's “Carmilla” (1872) and Anthony Burgess's A Clockwork Orange (1962).
\end{abstract}

Keywords: British literature; censorship; horror fiction; politics; reception studies; religion; sex

\section{Temna plat britanske grozljive proze: politika, tabuji in cenzura}

\section{POVZETEK}

Prvi britanski gotski romani so z značilnimi pošastnimi liki, obilnim nasiljem, eksplicitno spolnostjo in najrazličnejšimi grozljivimi prizorišči začeli zbujati pozornost pred skoraj dvema stoletjema in pol. Recepcija tovrstne književnosti je bila večinoma zelo pozitivna, tu in tam pa tudi kontroverzna. $\mathrm{V}$ članku predstavim načine, na katere britanska grozljiva proza - poleg vabljivosti skrivnostnega in privlačnosti temne plati - naslavlja bralske skrite želje in fantazije $s$ transgresivnimi političnimi, religioznimi in seksualnimi vsebinami, ki pogosto ne upoštevajo tabujev in spodobnosti. $\mathrm{V}$ ta namen bom analiziral tri znane pisce in dela iz treh različnih obdobij: Meniha (1796) Matthewa Gregoryja Lewisa, „Carmillo« (1872) Josepha Sheridana Le Fanuja in Peklensko pomarančo (1962) Anthonyja Burgessa.

Ključne besede: Britanska književnost; grozljiva proza; recepcijske študije; cenzura; seks; politika; religija 


\section{The Dark Side of British Horror Fiction: Politics, Taboos and Censorship}

\section{Introduction}

British horror fiction has enjoyed enormous popularity since the first Gothic novels appeared in the second half of the eighteenth century. Indeed, research shows that by the 1790s "Gothic" was the most popular form of writing in Britain (Cf. Gamer 2000, 50). As other types of horror stories $^{1}$ developed in the nineteenth and twentieth centuries, monsters of all kinds, including ghosts, werewolves, vampires and zombies, have attracted the attention of people from all walks of life. The popularity of the genre remains undiminished today, even when the figure of the vampire has been degraded, as in Stephenie Meyer's novel and later film Twilight, where Bram Stoker's Count Dracula is turned into an American teenager who goes to high school and protects the beautiful Bella Swan from evil vampires. On the whole, the appeal of the horror story has traditionally been explained in terms of the entertainment value of shock and repulsion, the attraction of violence and evil, as well as the lure of facing our hidden fears in a fantasy world. ${ }^{2}$

Nevertheless, it has sometimes been pointed out that part of the attraction of horror fiction derives from the way these stories dramatize our innermost desires and secret longings. Thus, Ken Gelder, in his collection of essays The Horror Reader, states that Dracula is a highly attractive figure because he combines "terror with an erotic awakening, drawing out latent inner desires" $(2000,146)$. These secret desires, and this is my argument here, revel in forbidden pleasures, entangled in taboos and social prohibitions, which are not only erotic in nature, but are usually associated with a political and religious message. That is the reason why the reception of these horror stories among critics and institutions has often met with controversies and difficulties. I will illustrate this argument with a discussion of three representative narratives from different periods, the well-known classics The Monk (1796) by Matthew Lewis, "Carmilla" (1872) by Joseph Sheridan Le Fanu, and A Clockwork Orange (1962) by Anthony Burgess. In line with the theoretical framework proposed by reception studies research, the reactions of reviewers and mainstream critics will be taken into account. Furthermore, in order to understand the public concerns about and transgressive nature of this fiction, references will be made to some cases of British editorial censorship, which will be contrasted with a quick glance at one specific overseas context: the Spanish institutional censorship that occurred during Franco's regime (1939-1975).

\section{The Monk by Matthew Lewis}

In The Monk Lewis presents the violent downfall of Ambrosio, a pious, well-respected abbot in Spain who goes from virtue to complete evil. First, he is overcome by the carnal lust of the wicked Matilda, who had been disguised as a male novice, and then he is stricken with desire for the innocent Antonia, whom he later rapes and kills, although she eventually turns out to be his younger sister. The story includes the characteristic elements of the Gothic novel ghostly apparitions, ancient monasteries, bad weather, fortune-telling gypsies, shadowy crypts,

In what follows the term "horror fiction" will be used in a generic sense without any attempt to delineate differences between "horror," "terror" or "Gothic".

For some good studies on the characteristics of horror fiction, see Barron (1990), Mulvey-Roberts (1998), Punter (1999), Wisker (2005), Colavito (2008) and Suchelli (2014). 
witchcraft, magic and pacts with the devil. But it also brings in some "transgressive" passages with scenes of sexual perversity and acts of horrendous brutality. ${ }^{3}$ Here is a taste of the language used in the scene after Ambrosio succumbed to Matilda's seduction:

As She [Matilda] spoke, her eyes were filled with a delicious languor. Her bosom panted: She twined her arms voluptuously around him [Ambrosio], and glewed her lips to his. Ambrosio again raged with desire. [...] He gave a loose to his intemperate appetites: While the fair Wanton put every invention of lust in practice, every refinement in the art of pleasure, which might heighten the bliss of her possession, and render her Lover's transports still more exquisite. $(1998,224)$

It is noteworthy that the novel was widely read by women, as the satirical engraving by James Gillray Tales of Wonder (1802) shows. This picture reveals the fascination The Monk held for middle-class ladies of the time, showing a group of ladies in fashionable clothes sitting around a table listening to another young woman who is reading aloud from Lewis's novel; while an old woman's face seems to indicate moral outrage, a young lady is listening with great interest and excitement. Perhaps they are in the middle of a passage in which the erotic character of Matilda, "a sensual woman who wields natural and supernatural powers," plans to make men her victims (Nichols 1983, 201).

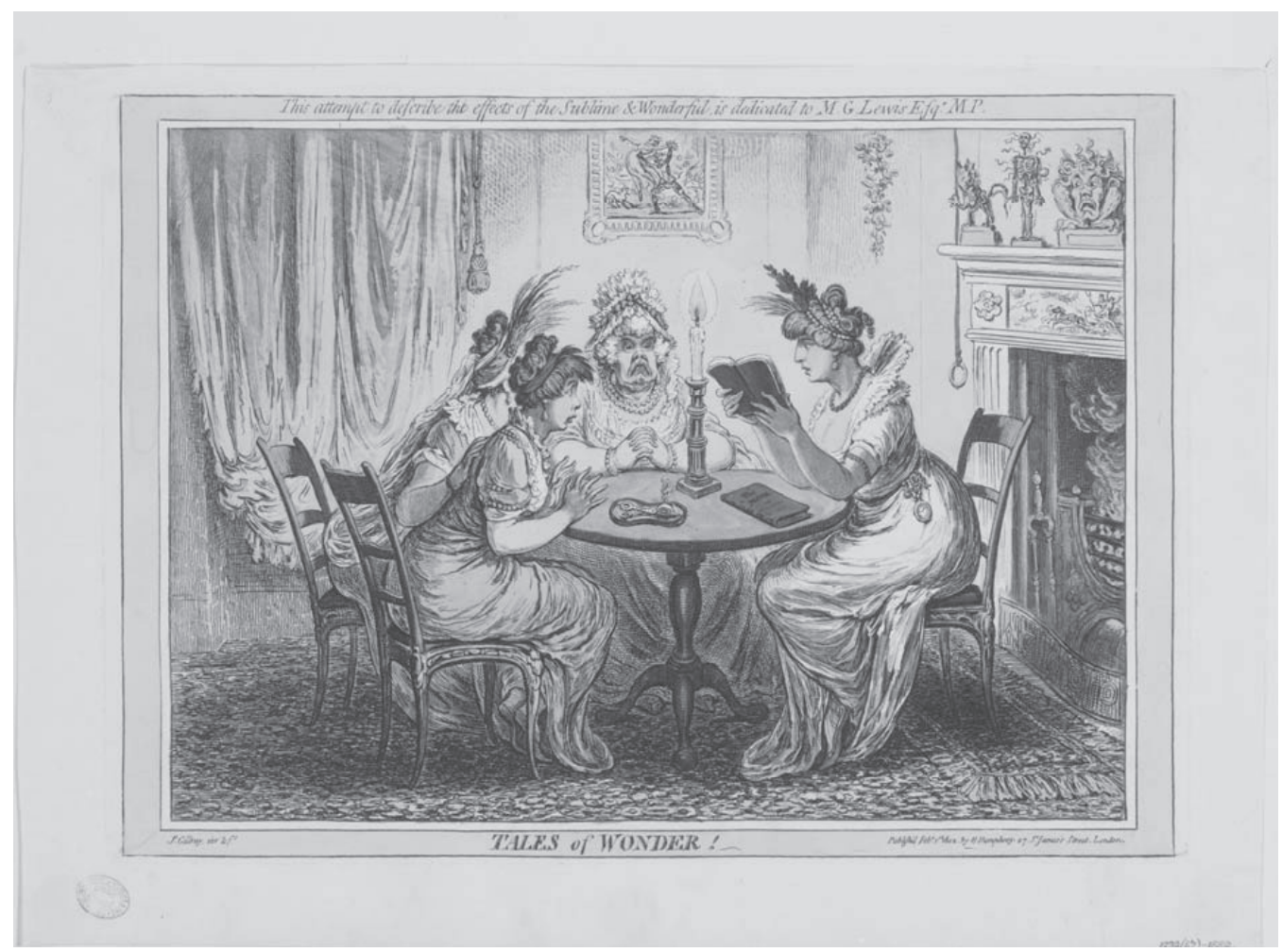

Figure 1. James Gillray - Tales of Wonder (1802). (C) Victoria and Albert Museum, London.

Some academic criticism has focused more intently on the sexual themes of this novel. See Mac Andrew (1979), Twitchell (1987) and Winter (1992). 
The Monk is a lurid tale of ambition, murder and perversion that not only seems to test the limits of propriety and moral decorum, but also to launch an attack on monastic corruption. Lewis's intention to criticise religious orders has traditionally been associated with other anti-religious publications that appeared in France before the Revolution. ${ }^{4}$ Here one could identify some of the political issues raised in the novel. It seems that at that time British readers and critics could also regard clerical libertinism as "closely allied with the revolutionary radicalism" (Ellis 2000, 93). What is more, linked to this representation of monastic life as immoral and depraved is the traditional Protestant prejudice against Roman Catholicism, with its perceived political and religious authoritarianism, its superstitious tendencies and cloistered lifestyles. We cannot forget that the story is set in a sinister Capuchin monastery in Madrid, during the time of the Spanish Inquisition. ${ }^{5}$ The cruelty of the Inquisition, together with religious fanaticism and the abuse of indigenous people in the American colonies, were the major ingredients in the development of the "Black Legend" that the British so often used to vilify the Spanish empire.

The Monk had immediate popularity and commercial success. It went through three editions within the first year and received enthusiastic reviews in publications closely associated with the Whigs and radical intellectual groups, such as The Morning Chronicle and The Analytical Review. ${ }^{6}$ However, it was labelled obscene by some other critics, including Samuel Taylor Coleridge, who writing for the Critical Review stated that it was a blasphemous story and warned that if a parent saw The Monk in "the hands of a son or daughter, he might reasonably turn pale" $(1797,197)$. The scandal that erupted about the novel coincided with Lewis's election as a member of the House of Commons; therefore, critics like Rev. Thomas Mathias, an anti-Jacobin Tory polemicist, declared the book was "an offence to the public" that had been written by a supposedly elected guardian and defender of the laws and good manners, and called for legal action against the author and the novel itself (1798, 291-96).

The reaction was so strong that there was even an official move to suppress Lewis's tale instigated by the Society for Carrying into Effect His Majesty's Proclamation against Vice and Immorality. As a part of a wider movement to improve the nation's morals, in 1787 this Society, also known as the Proclamation Society, was established by William Wilberforce, a Tory MP who was also known as a key figure in the movement to end the slave trade. Its main aims were "to check the rapid progress of impiety and licentiousness, to promote a spirit of decency and good order, and to enforce a stricter execution of the laws against vice and immorality" (Tomkins 2010, 57). ${ }^{7}$ According to Lewis's biographer D. L. Macdonald, the Proclamation Society instructed the authorities to curtail the sale of the novel $(2000,134)$. Although there is no evidence to show how the case was resolved, all this pressure from critics and censors prompted Lewis to revise his work and expurgate some objectionable passages from the fourth edition that was published in 1798, under the new title Ambrosio; or, The Monk. In this censored version Lewis softened

4 Emma McEvoy, in her introduction to the Oxford World's Classics edition of The Monk, cites the European Magazine of 1797 as a source for this comparison between Lewis's attack on religious orders and some French anti-religious publications before the Revolution.

5 The novel is set at an unspecified historical period; perhaps, the sixteenth or seventeenth century (there are references to Cuba and other places in the New World, so it must be after 1492).

6 For a discussion of the contemporary critical response to The Monk see Ellis (2000, 109-13) and McEvoy's introduction to the Oxford World's Classics edition of this novel (1998).

This Society succeeded in sending a bookseller named Thomas Williams to jail, charged with seditious and blasphemous libel, for publishing Thomas Paine's attack on traditional religion, The Age of Reason (Macdonald 2000, 133) 
the language - "incontinence" to "weakness," "lust to "desire" and "desires" to "emotions" (Macdonald 2000, 134) - and removed explicit references to sexual activity, descriptions of naked female bodies as well as that section in which Antonia is found reading a version of the Bible given to her by her mother from which scenes of vice had been removed. ${ }^{8}$

The new expurgated edition had a positive response from both critics and readers, who might well have been attracted by the scandal and controversy surrounding the story. A review of this fourth edition published in the Monthly Mirror claims that now that Lewis has removed the "objectionable passages" the novel is "deserving of the very extraordinary favour it has received from the public" (cited in Perraux 1960, 59). By 1800, as Louis F. Peck shows, "five London and two Dublin editions to say nothing of pirated versions and abridgments, were needed to supply the market" $(1961,28)$. In the years since, The Monk has never ceased to attract or repel readers and critics. Today, stimulated by the renaissance in Gothic studies in general, interest in this novel and other Gothic works has never been higher. ${ }^{9}$

Even in Spain, the country of the lascivious monk and Inquisition portrayed by Lewis, the novel has long captured the interest of a wide readership. The first Spanish translation, anonymous and entitled El fraile, o historia del padre Ambrosio y de la bella Antonia, came out in Madrid as early as 1822. There was also another illustrated Spanish translation by León Compte, published by the Editorial Juan Pons in 1870 under the title El fraile. ${ }^{10}$ Nowadays, one can find several editions of Lewis's novel issued by prestigious publishing houses, such as Editorial Bruguera, Círculo de Lectores and Cátedra. What is indeed surprising is that the book's anti-clericalism and obscenity was not a serious concern for the Catholic censors of Franco's regime, a period in which a strict system determined what was morally or politically correct. ${ }^{11}$ They allowed the publication of The Monk in 1970. It is true that a couple of reports from the censorship office warned against the "entirely negative view of religious life even in its higher levels," but it was eventually accepted, "given the quality of the work". ${ }^{12}$

\section{3 “Carmilla" by Joseph Sheridan Le Fanu}

John Sheridan Le Fanu is another major figure among writers of Gothic and horror fiction, mainly known for his short stories and for such sensationalist novels as Wylder's Hand (1863), Uncle Silas (1864) and The Rose and the Key (1871). Critics have praised them for their suggestive and detailed descriptions of physical settings, their insightful characterisations and Le Fanu's mastery of Gothic conventions. ${ }^{13}$ One of his best-known stories is "Carmilla," published in the collection In a Glass Darkly in $1872 .{ }^{14}$ Set in a remote Eastern European castle, it features a

8 For a detailed study of Lewis's changes in his fourth edition of the novel, see the fifth chapter of Joseph James Irwin's M. G. "Monk" Lewis (1976) entitled "Expurgation of The Monk".

$9 \quad$ Frederick S. Frank's bicentennial bibliography (1997) verifies this interest.

10 These translations are cited in José Fernández Montesinos's Introducción a una historia de la novela en España (1955, 80 and 218).

11 On censorship in post-war Spain, see Abellán (1980), Beneyto (1977) and Cisquella (1977).

12 See File 12455-69, Box 66/03686. Files on censorship of this period are found in the "Fondo de Cultura" at the Archivo General de la Administración (Alcalá de Henares, Madrid). I am indebted to the archive staff for their unstinting help and friendly guidance on how to find my way through the complexities of these files. All translations from the Spanish are my own.

13 See, for instance, McCormack (1997), Sage (2004) and Walton (2007).

14 The story, first published in four successive issues in the short-lived Victorian periodical The Dark Blue between December 1871 and March 1872, reappeared as the last of the five stories comprising In a Glass Darkly. 
female vampire who seduces a young woman named Laura and drains her lifeblood over a period of weeks. "Carmilla" is the first prose tale in English literature whose protagonist is a female vampire, and it has become a classic in vampire literature. ${ }^{15}$

Laura's strange fascination with her attractive evil friend has been interpreted in different ways. Whilst some have seen "Carmilla" as a straightforward horror story, others have suggested various interpretations of this vampiric relationship. Some critics have highlighted the lesbian undertones of this rapport between the two women. In fact, over the last few decades some scholars have explored the theme of repressed sexuality within the story and suggested that Le Fanu offered a commentary on attitudes towards female sexuality in Victorian society. ${ }^{16}$ Similarly, when the story was adapted for the big screen, the lesbian undercurrent was noted by film directors, such as Roger Vadim in Et mourir de plaisir (Blood and Roses, 1960), starring Mel Ferrer, Annette Vadim and Elsa Martinelli. All this does not come as a surprise, since in the story Carmilla and Laura are often presented together in bed, holding hands, kissing each other passionately, gazing into each others' eyes, walking with their arms about the other's waists, and having erotic conversations:

She kissed me silently.

"I am sure, Carmilla, you have been in love; that there is, at this moment, an affair of the heart going on."

"I have been in love with no one, and never shall," she whispered, "unless it should be with you."

How beautiful she looked in the moonlight! $(1923,404)$

In addition, the concluding, explanatory section of the tale also hints at this lesbian relationship between a female vampire and her female victim when it is explicitly stated that

The vampire is prone to be fascinated with an engrossing vehemence, resembling the passion of love, by particular persons. [...] it will, in these cases, husband and protract its murderous enjoyment with the refinement of an epicure, and heighten it by the gradual approaches of an artful courtship. (1923, 468-69, the emphasis is mine)

Le Fanu seems to defy the established patriarchal systems of relationships when he allowed the women of "Carmilla" to escape their traditional roles as victims of a male seducer (see Signorotti 1996). Instead of creating a monster, like Dracula, who seeks to take control of a woman's body for the purposes of male pleasure, Le Fanu depicts a society where women assume the aggressive roles while men become relegated to less powerful positions. Laura's father even remains nameless throughout the story.

Once more, in "Carmilla" sexual desires and eroticism seem to be mixed with other political and religious interpretations, some of them focusing on the religious perversions of Catholicism. Taking into account that Le Fanu was born in Dublin to a Protestant family of Huguenot descent, the Oxford editor of the stories, Robert Tracy, suggests that the anxieties of "Carmilla" are mainly social and political (1993, xix-xx). He reads it as a tale of the displaced Anglo-Irish who were losing their importance in Ireland. Just as Laura's father is a displaced Englishman

15 It has been argued that "Carmilla" is an adaptation of Coleridge's poem Christabel; see Nethercot (1949), Twitchell $(1981,129)$ and Andriano (1993, 98-99).

16 See, for example, Castle (1993), Signorotti (1996), Thomas (1999), Palmer (1999) and Coffman (2006). 
living abroad, so, too, Le Fanu's father was a minister of the (Anglican) Church of Ireland, which ended its role as state church with the Irish Church Act of 1869 (that took effect in 1871). This act meant not only the end of state support, but also enabled the government to take control of much of the church's property. Another critic, Patrick O'Malley points to the national and religious issues involved in Carmilla's vampirism. He argues that this story shows the tension between English domesticity and Protestantism, represented by Laura, and the foreign Catholic roots of Carmilla: "Straddling the boundary of Englishness and Irishness, Protestantism and Catholicism, Anglo-oriented nationalism and foreign ancestry, Le Fanu stands in a multiply determined relationship to the stability of categorical classifications [...]" (2006, 143). In other words, Le Fanu seems to establish a contrast between the Anglo-Protestant background of the good character and victim, Laura, and the foreign and Catholic nature of the monster, Carmilla.

As in Lewis's novel, Carmilla's story is set abroad, in Styria, a region today located southern Austria, north of Slovenia. ${ }^{17}$ It seems that these kind of horrendous events and experiences can only happen in foreign countries. Whereas Laura's family is associated with the rational and Protestant English tradition, the vampiric Carmilla is linked to the "appalling superstition that prevails in Upper and Lower Styria" (1923, 465), lands of predominantly Catholic families. Since, in the end, the vampire is destroyed, the story might represent the victory of Protestantism over Catholicism. However, even at the end, "like Laura, England cannot get Catholicism or sexual deviance out of its blood or out of its mind” (O’Malley 2006, 146).

It is interesting to note that, contrary to the scandal evoked by the publication of Lewis's The Monk, no controversy among reviewers and critics has been recorded regarding the sexual undertones of "Carmilla." ${ }^{18}$ One may ask whether the Victorian readers of the time recognised the implied lesbianism as a twentieth-first century reader would do. ${ }^{19}$ What is certain, however, is that Laura, the victim, never realises the implications of the sexual relationship that she is taking part in, and therefore, her mind retains its purity. Perhaps that is also the reason why Spanish censors never identified the erotic elements in the story as a form of perversion, and allowed it to be published several times without any cuts or amendments, despite the moral constraints established by the Catholic Church during Franco's regime. ${ }^{20}$ The censors' reports did not mention any trace of transgressive sexual behaviour between the two female characters, even when some of the editions included suggestive and daring illustrations. It is indeed surprising that the Spanish censorship office did not find these images offensive or immoral, although they feature naked women, old and young, and women in very sensual robes and poses. One of these illustrations even clearly shows the two protagonists in what might be considered a lesbian attitude, sitting very close together, with heads touching and one arm around the waist of the other. Nevertheless, these illustrations were allowed to be printed.

${ }_{17}$ Laura's castle is ten leagues (about $48 \mathrm{~km}$ ) from the city of Graz.

18 Even if there had been some controversies, Le Fanu might not have been able to follow them or practice any form of self-censorship, as Lewis did, because he died only a few months after "Carmilla" was published in book form.

19 Sara Putzell-Korab reminds us that Denis Diderot's La religieuse (1796), which centres on the physical seduction of a nun by the Mother Superior, went through twenty English editions between 1800 and 1870 (1984, 181).

20 In 1941 permission was granted to import 1,000 copies of a Spanish version published in Narraciones Terrorificas, a magazine edited in Argentina; see File EXT-921-41, Box 21/07067. In the 1960s and 1970s Spanish censors also gave the green light to "Carmilla" again and again, when it was published in several collections of horror stories. For a detailed analysis of the reception and censorship of "Carmilla" see Lázaro (2010). 

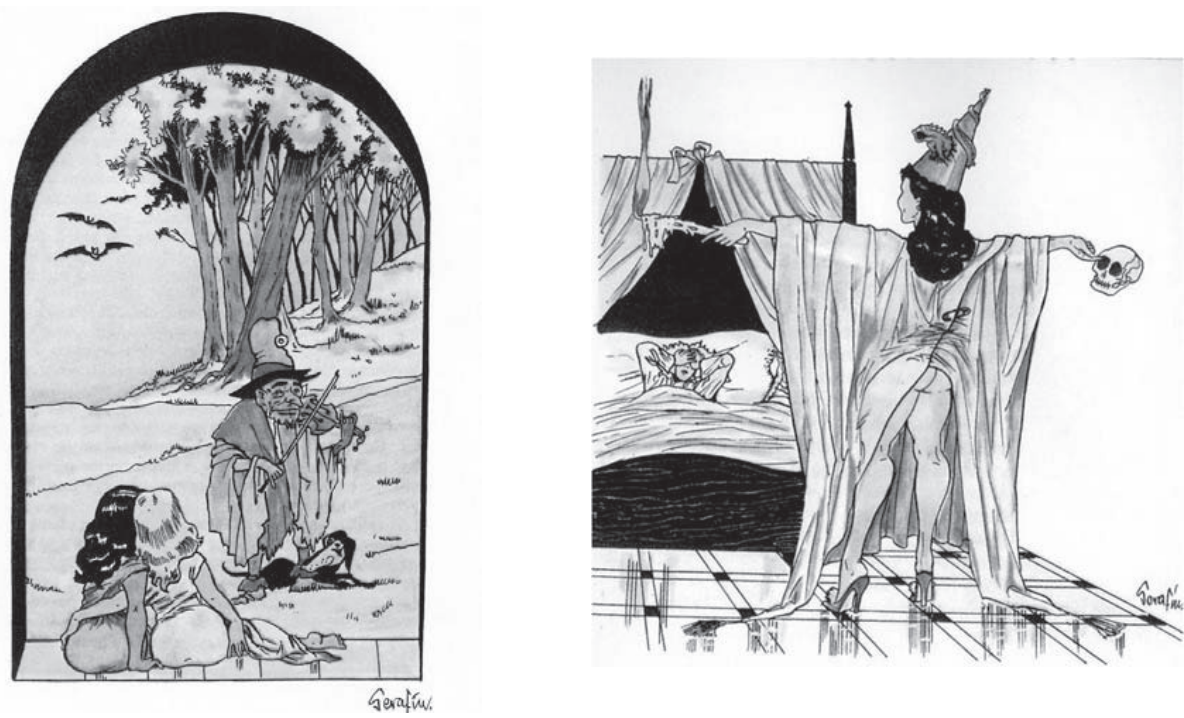

Figure 2. Images by Serafín, from the illustrated edition of Narraciones Terrorificas (1961).

Despite all the erotic images and manifestations of homosexual feelings, neither nineteenthcentury Victorian critics nor twentieth-century Spanish censors perceived the story as immoral, and it is likely, as noted above, that they did not see its lesbian content. Expressions of love and close relationships between women had traditionally been viewed as entirely innocent and without suspicion. Whereas displays of affection between men were not acceptable at all, girls and women exhibiting such amorous behaviour were not assumed to be homosexual, and so these relations were often free from public scrutiny. It was Freud's psychoanalytic theories and some other studies by sexologists in the early decades of the 20th century that began to regard those "too close" friendships between women in a different way. Be that as it may, "Carmilla" enjoyed an excellent reception, and was frequently republished in English and translated into Spanish.

\section{A Clockwork Orange by Anthony Burgess}

Since the mid-twentieth century horror fiction has expanded its boundaries and the traditional intrusion of the supernatural element might now be replaced by any morbid, gruesome, surreal or frightening theme. Not only vampires and demons populate these stories, but also psychopathic killers and mutant arthropods. Horror fiction now often overlaps science fiction or other types of fantasy. ${ }^{21}$ Although A Clockwork Orange was not first marketed or reviewed as a horror story, with the passing of the years it has gained a following among the horror community. ${ }^{22}$ The key element of horror in this story is the nightmare vision of a near-future world dominated by sex, violence and a corrupt bureaucracy in a repressive totalitarian super-state. The monster here is a teenager called Alex, the vicious leader of a gang of criminals that rob, rape, torture and murder for fun. The word "horrorshow" is part of his usual vocabulary, the "Nadsat" language used by this character; this term represents a transformation of the Russian khorosho ("good") and the

${ }_{21}$ For an illustrative discussion of "horror" in literature see Botting (1998, 123-31).

22 The film adaptation by Stanley Kubrick has often been included in books and discussions about horror films; see, for instance, Muir (2002) and Hogan (1986, 135-36). 
English "horror show." What Alex describes as "horrorshow" is usually connected with violence and the horrors he commits. During one of the brainwashing sessions he calls the film he is watching a "real horrorshow film," to which he receives a suggestive response: "Horrorshows is right, friend. A real show of horrors" $(2012,112)$.

Apart from Burgess's invention of "Nadsat," what contributed to the novel's success and notoriety were the explicit scenes of sex and violence. One of the most striking take place at the beginning of the story, when Alex and his gang got into a cottage labelled "HOME," beat up the man living there, a writer with a manuscript entitled $A$ Clockwork Orange, and rape his beautiful wife while making the man watch. In another scene, the protagonist also rapes two young girls, Marty and Sonietta, after having drugged them with an aphrodisiac. Sex in the novel is presented as an exhibition and assertion of power and violence. Alex is described as a violent and sadistic monster who simply enjoys having these experiences. He insists that he does evil because he likes it and is in full charge of his actions, illustrating Burgess's argument that free will is necessary, even though the consequences might be negative. It comes as no surprise that his Heinemann editor, James Michie, was worried about these episodes of sexual violence in the novel; he was afraid that "a delicate-minded critic could convincingly accuse him [Burgess] of indulging in sadistic fantasies" (cited by Biswell 2012, xiv), and thus the novel would be prosecuted and banned under the 1959 Obscene Publications Act, which would damage Burgess's reputation. Despite these worries, the novel was eventually published by Heinemann in 1962.

Another horrific feeling assaults the reader's sensibility when Alex is taken to jail for his vicious crimes and the state tries to suppress his freedom by psychologically removing his power to make free choices. The intention of the government is to reform and "redeem" him, but at what cost? A Clockwork Orange is a frightening political and moral dystopia about good and evil, and about the meaning of human freedom. Burgess's provocative suggestion is that removing Alex's ability to choose, no matter how monstrous his behaviour may be, is morally wrong. The state's experimental treatment for crime control turns Alex into an automaton (a clockwork man), which represents a greater evil than any of his crimes. However, the novel has a positive ending. In the last chapter, the protagonist truly grows as a human being, after the government removes his conditioning, and he is allowed the conscious decision to renounce violence, that is to say, to choose good over evil.

What is significant about the publication history of $A$ Clockwork Orange is that the American version of the novel was published without this final chapter, which the publisher, Norton, found to be unconvincing. Burgess reluctantly agreed, mostly for financial reasons, ${ }^{23}$ though he strongly disapproved of this decision, since he believed the American publisher had distorted the novel into a nasty tale of unredeemable evil. Ironically, it was the American edition of the novel that became a cult classic among college students (Whissen 1992, 62-67), and it was also the edition that Stanley Kubrick used for his 1971 film adaptation. The film, like Lewis's The Monk, was both commercially successful and highly controversial. The stark terror of the novel was very well captured in Kubrick's work, which was initially labelled with an X rating and widely criticized for glorifying sex and violence. Some called it "an evil motion picture" which promoted "the kind of nihilism that has political purposes not all of which the young perceive" (Hart

23 This is the explanation Burgess gave in his introduction to the 1986 Norton edition, which restored the book to its original length: "I needed money back in 1961, even the pittance I was being offered as an advance, and if the condition of the book's acceptance was also its truncation - well, so be it" (1986, vi). 
1972, 51). There were even reports of riots and street violence after screenings (Morrison 2000, 1). In Britain, the British board film also passed it with an X certificate, and in 1974 Kubrick himself imposed a ban and withdrew the film from distribution in the UK. ${ }^{24}$ It was only released again in 2000 (Morrison 2000, 1). The novel was also withdrawn from some American schools and libraries on grounds of immorality and violence (Sova 1998, 76-79; Turner 2011, 14). It is difficult to know to what extent the omission of that last chapter in the American edition affected the interpretation of the novel and film, and thus stimulated the controversy. What cannot be denied is that $A$ Clockwork Orange became Burgess's most popular novel and one of Kubrick's most profitable films. ${ }^{25}$

In Spain, Burgess's dystopia was not so popular. Readers had to wait until 1976 to hold a Spanish translation of the American edition in their hands. Perhaps, as an act of self-censorship, no publisher dared to ask the censors for authorisation before, fearing a negative answer. It was only a few months after Franco's death that a Barcelona publisher, Edhasa, presented a copy of this novel to the still-running censorship office. The censors did not ban its publication but could not resist the impulse to bend the top corner of those pages that they found morally or politically offensive in the copy they read. ${ }^{26}$ As one might expect, among the marked pages were those that included the brutal rape of the writer's wife and the sexual scene with the drugged girls. The censors also disliked the disrespectful references to the prison chaplain, an alcoholic priest who preaches to the prisoners about morals, but accepts the cruel treatment that Alex receives at the hands of the government, at least for some time. It is true that this character seems to voice Burgess's Catholic position when he insists that Alex must have moral choices, as when he asks Alex "What does God want? Does God want goodness or the choice of goodness? Is a man who chooses the bad but perhaps in some way better than a man who has the good imposed upon him?" (Burgess 2012, 105). However, this priest appears as a naïve, selfish, ridiculous character, so the Spanish censors could not help but react to that.

\section{Conclusion}

Despite the uncertainties over the interpretation of texts such as "Carmilla" or the American edition of $A$ Clockwork Orange, we can come to the conclusion that horror stories usually imply more than they apparently say. They are not simply entertaining stories based on fear and gruesome effects. Behind the crimes, cruelties and other events of a terrifying nature, these horror narratives are often concerned with political, religious, moral and sexual issues. It could be the threat of Catholic perversion or some revolutionary ideals, as in The Monk; it may be national tensions or repressed sexuality, as in "Carmilla"; or perhaps the importance of individual free will, as in A Clockwork Orange. Whatever the issues are, they tend to play along the boundaries of social rules and taboos imposed by the dominant, conservative ideology.

Sexuality, linked to violence, is a recurrent motif that often has a disruptive presence in this type of literature. These stories seem to appeal to the private passions and inner desires of human beings as they relate to lust, physical pleasures and control of the Other. It seems that the horrible monster is not so much a threat from a foreign world as one from inside ourselves. What is more,

\footnotetext{
24 Kubrick never provided an explanation for banning the film in Britain (Polman 1993, 13).

25 In 2000, David Cook wrote that A Clockwork Orange was "Kubrick's most profitable film to date, returning $\$ 17.5$ million on a \$2-million investment and ranking eighth in box-office returns for 1971 (77).

26 See File 1762-76, Box 76/16.
} 
no matter if it is the erotic icon of a passive and innocent female victim suffering at the hands of a savage male monster, or if the horror appears instead in women's clothes, with a pale beauty, it usually entails a deviance from the social and moral norms that are accepted by society. That is why horror fiction has sometimes been placed at the centre of polemics and subjected to various types of censorship. The transgressive nature of horror fiction, and the controversies it often generates, are an important part of its attraction and one of the reasons why such works have long been so appealing and popular.

\section{References}

Abellán, Manuel L. 1980. Censura y creación literaria en España, 1939-1976. Barcelona: Ediciones Península.

Andriano, Joseph.1993. Our Ladies of Darkness: Femenine Daemonology in Male Gothic Fiction. University Park, PA: The Pennsylvania State University Press.

Barron, Neil. 1990. Horror Literature: A Reader's Guide. New York: Garland.

Beneyto, Antonio. 1977. Censura y política en los escritores españoles. Barcelona: Plaza y Janés.

Biswell, Andrew. 2012. “Introduction.” In A Clockwork Orange: the Restored Edition by Anthony Burgess, viixxvii. New York, NY: W. W. Norton.

Botting, Fred. 1998. “Horror.” In A Handbook to Gothic Literature, edited by Marie Mulvey-Roberts, 123-31. Basingstoke, Hampshire: Palgrave Macmillan.

Burgess, Anthony. 1986. "Introduction: A Clockwork Orange Resucked.” In A Clockwork Orange, v-ix. New York, NY: W.W. Norton \& Company.

—. 2012. A Clockwork Orange: the Restored Edition. New York, NY: W. W. Norton.

Castle, Terry. 1993. The Apparitional Lesbian: Female Homosexuality and Modern Culture. New York: Columbia UP.

Cisquella, Georgina, José Luis Erviti, and José A. Sorolla. 1977. Diez años de represión cultural: la censura de los libros durante la ley de prensa (1966-76). Barcelona: Anagrama.

Coffman, Christine E. 2006. Insane Passions: Lesbianism and Psychosis in Literature and Film. Middletown, CT: Wesleyan University Press.

Colavito, Jason. 2008. Knowing Fear: Science, Knowledge and the Development of the Horror Genre. Jefferson, NC: McFarland.

Coleridge, Samuel Taylor. 1797. "Review of Matthew G. Lewis, The Monk." The Critical Review 19 February: 194-200.

Cook, David. 2000. Lost Illusions: American Cinema in the Shadow of Watergate and Vietnam, 1970-1979. New York, NY: Scribner.

Ellis, Markman. 2000. "Revolution and Libertinism in the Gothic Novel." In The History of the Gothic Fiction, 81-120. Edinburgh: Edinburgh University Press.

Fernández Montesinos, José. 1955. Introducción a una historia de la novela en España. Madrid: Editorial Castalia.

Frank, Frederick S. 1995. "M. G. Lewis's The Monk after Two Hundred Years, 1796-1996: A Bicentenary Bibliography." Bulletin of Bibliography 52 (3): 241-60.

Gamer, Michael. 2000. Romanticism and the Gothic: Genre, Reception, and Canon Formation. Cambridge: Cambridge University Press. 
Gelder, Ken. 2000. “Introduction to Part Five.” In The Horror Reader, 147-47. London: Routledge.

Hart, Henry. 1972. “A Clockwork Orange: Review.” Films in Review 23 (1): 51.

Hogan, David J. 1986. Dark Romance: Sexuality in the Horror Film. Jefferson, NC: McFarland.

Irwin, Joseph James. 1976. M. G. "Monk” Lewis. New York: Twayne.

Lázaro, Alberto. 2010. "Spanish Readings of Le Fanu's 'Carmilla'." In In the Wake of the Tiger: Irish Studies in the Twenty-First Century, edited by David Clark and Rubén Jarazo Álvarez, 81-92. La Coruña: Netbiblo.

Le Fanu, Joseph Sheridan. 1923. In a Glass Darkly. London: Eveleigh Nash \& Grayson.

—. 1961. "Carmilla." In Narraciones Terrorificas: Antología de cuentos de misterio (Segunda Selección), translated by anon, edited by Ana Ma Perales, 69-128. Barcelona: Ediciones Acervo.

Lewis, Matthew. 1998. The Monk. Oxford: Oxford University Press.

—. 1922. El Fraile, o historia del padre Ambrosio y de la bella Antonia. París: Librería de Rosa.

Mac Andrew, Elizabeth. 1979. "Characters - The Split Personality." In The Gothic Tradition in Fiction, 86-93. New York: Columbia University Press.

McCormack, W. J. 1997. Sheridan Le Fanu. 3rd ed. Gloucestershire: Sutton.

Macdonald, David Lorne. 2000. Monk Lewis: A Critical Biography. Toronto: University of Toronto Press.

MacEvoy, Emma. 1998. "Introduction." In The Monk by Matthew Lewis, edited by Howard Anderson, viixxx. Oxford: Oxford University Press.

Mathias, Thomas. 1798. The Pursuits of Literature: A Satirical Poem in Four Dialogues. 5th ed. London: T. Becket.

Morrison, Blake. 2000. "The Shock of the Droog It's Even More Potent Today than It Was 28 Years Ago. Blake Morrison on the Return of A Clockwork Orange." The Independent, March 5, 2000: 1, 4.

Muir, John Kenneth. 2002. Horror Films of The 1970s, Vol. 1. Jefferson, NC: McFarland.

Mulvey-Roberts, Marie, ed. 1998. The Handbook of Gothic Literature. Basingstoke, Hampshire: Palgrave Macmillan.

Nethercot, Arthur H. 1949. “Coleridge's 'Christabel' and LeFanu’s 'Carmilla.” Modern Philology 47 (1): $32-38$.

Nichols, Nina daVinci. 1983. "Place and Eros in Radcliffe, Lewis, and Bronte." In The Female Gothic, edited by Juliann E. Fleenor, 187-206. Montreal: Eden Press.

O’Malley, Patrick R. 2006 “Carmilla: the Vampire as National Infiltrator.” In Catholicism, Sexual Deviance, and Victorian Gothic Culture, 138-46. Cambridge: Cambridge UP.

Palmer, Paulina.1999. Lesbian Gothic: Transgressive Fictions. London: Cassell.

Peck, Louis F. 1961. A Life of Matthew G. Lewis. Cambridge, MA: Harvard University Press.

Perraux, André. 1960. The Publication of The Monk: A Literary Event, 1796-1798. Paris: Marcel Didier.

Polman, Dick. 1993. "No Droogs, Please, We're British: After 20 years, Clockwork Orange is Still Banned in the U.K." The Spectator, November 13, 1993: 13.

Punter, David, ed. 1999. A Companion to the Gothic. Oxford: Blackwell.

Putzell-Korab, Sara. 1984. "Passion between Women in the Victorian Novel." In Sexuality and Victorian Literature, edited by Don Richard Cox, 180-95. Knoxville, TN: University of Tennessee Press.

Sage, Victor. 2004. Le Fanu's Gothic: The Rhetoric of Darkness. Basingstoke, Hampshire: Palgrave Macmillan. 
Sauchelli, Andrea. 2014. "Horror and Mood." American Philosophical Quarterly 51 (1): 39-50.

Signorotti, Elizabeth. 1996. "Repossessing the Body: Transgressive Desire in 'Carmilla' and Dracula." Criticism 38 (4): 604-32.

Sova, Dawn B. 1998. Literature Suppressed on Social Grounds. New York, NY: Facts on File.

Thomas, Tammis Elise. 1999. "Masquerade Liberties and Female Power in Le Fanu's 'Carmilla." In The Haunted Mind: The Supernatural in Victorian Literature, edited by Elton E. Smith and Robert Haas, 39-65. New York: University Press of America.

Tracy, Robert, ed. 1993. "Introduction.” In a Glass Darkly by Sheridan Le Fanu, vii-xxxiii. Oxford: Oxford University Press.

Tomkins, Stephen. 2010. The Clapham Sect: How Wilberforce's Circle Transformed Britain. Oxford: Lion Hudson.

Turner, Robin. 2011. “They're 'Mad, Bad and Dangerous to Read' and Available in Brown Paper: Censorship Highlighted by 'Banned’ Book Season.” Western Mail, Cardiff, September 28, 2011: 14.

Twitchell, James B. 1981. The Living Dead: A Study of the Vampire in Romantic Literature. Durham, NC: Duke University Press.

—. 1987. "I Shall Be with You on Your Wedding Night': Incest in Nineteenth Century Popular Culture." In Forbidden Partners: The Incest Taboo in Modern Culture, 156-57. New York, NY: Columbia University Press.

Walton, James. 2007. Vision and Vacancy: The Fictions of J. S. Le Fanu. Dublin: University College Dublin Press.

Whissen, Thomas Reed. 1992. "A Clockwork Orange: Anthony Burgess.” In Classic Cult Fiction: A Companion to Popular Cult Literature. New York, NY: Greenwood Press.

Winter, Karl J. 1992. "Sexual/Textual Politics of Terror: Writing and Rewriting the Gothic Genre in the 1790s." In Misogyny in Literature: An Essay Collection, edited by K. A. Ackley, 89-103. New York, NY: Garland.

Wisker, Gina. 2005. Horror Fiction: An Introduction. New York: Continuum. 